\title{
Theoretical Description of Simple Electrode Processes
}

\section{Nørskov, Jens Kehlet}

Published in:

Meeting Abstracts - Electrochemical Society

Publication date:

2006

Document Version

Publisher's PDF, also known as Version of record

Link back to DTU Orbit

Citation (APA):

Nørskov, J. K. (2006). Theoretical Description of Simple Electrode Processes. In Meeting Abstracts Electrochemical Society (pp. Abstract 434). The Electrochemical Society.

\section{General rights}

Copyright and moral rights for the publications made accessible in the public portal are retained by the authors and/or other copyright owners and it is a condition of accessing publications that users recognise and abide by the legal requirements associated with these rights.

- Users may download and print one copy of any publication from the public portal for the purpose of private study or research.

- You may not further distribute the material or use it for any profit-making activity or commercial gain

- You may freely distribute the URL identifying the publication in the public portal

If you believe that this document breaches copyright please contact us providing details, and we will remove access to the work immediately and investigate your claim 
Theoretical description of simple electrode processes J. K. Nørskov

Technical University of Denmark

A method is introduced for calculating the stability of reaction intermediates of electrochemical processes as a function of bias on the basis of electronic structure calculations. The method is used in combination with detailed density functional theory (DFT) calculations to develop a description of the free energy landscape of electrochemical electrode processes of relevance to PEM fuel cells. A physical picture is developed of the trends in the electrocatalytic activity of different transition metals for hydrogen oxidation and oxygen reduction. 